\title{
Exogenous shocks, social skill, and power: Urban energy transitions as social fields
}

\author{
Article published in: Energy Policy 117 (2018): 307-315 \\ https://doi.org/10.1016/j.enpol.2018.03.035
}

Author:

Jens Koehrsen, Centre for Religion, Economy and Politics; University of Basel

Address: Jens Köhrsen, University Basel, Faculty of Theology, Nadelberg 10

4051 Basel, Switzerland.

Email: jens.koehrsen@unibas.ch 


\title{
Exogenous Shocks, Social Skill, and Power: Urban Energy Transitions as Social Fields
}

\begin{abstract}
The constantly growing scholarship on urban energy transitions needs a framework to analyze these transitions. This article proposes the Field Perspective (FP) as an approach for the study of urban energy transitions. FP analyses how the interplay of actors, who are dedicated to a similar purpose, and the structures guiding this interplay, co-evolve. By applying FP to the energy transition in the German city Emden, the article shows how the transition evolves through (a) alterations in the exogenous context of the city (e.g. national feed-in-tariffs for renewables), (b) the social skill and changing interplay of local actors engaged in the transition, and (c) the emergence of powerconstellations and rules.
\end{abstract}

Keywords: Field Perspective, Sustainability Transitions, Cities, Energy

\section{Introduction}

Urban energy transitions depend upon the interplay of various types of actors such as businesses, politicians, municipal employees, intermediaries, citizen initiatives, and scientists (Busch and McCormick, 2014; Blanchet, 2015; Gabillet, 2015; Mattes et al., 2015; Späth and Rohracher, 2013). Given the often substantial amount of actors, activities, and relationships in urban transitions, theoretical frameworks are needed to facilitate handling this complexity (cf. Truffer and Coenen, 2012). This article proposes the field perspective (FP) as a tool to describe the interplay of actors in the course of urban energy transition processes. FP is a social theory that analyses social action at the meso-level by focusing on relevant actors and their interests, the relationships between them, and the shared rules and understandings that frame their actions (Fligstein and McAdam, 2011; Fligstein and McAdam, 2012). It provides a heuristic framework that enables researchers to systematize actors and their interactions and to describe the co-evolution of social order and action, in the form of rules and power structures resulting from these interactions. Thereby it allows for the studying of how structures and actions in urban spaces change over time in ways that shape transitions towards sustainability.

This article explores the potentials of FP for the study of urban low carbon transformations by applying it to the energy transition in the German city, Emden. Employing this approach shows how the transition evolves through (a) alterations in the exogenous context of the city (e.g. national feed-in- 
tariffs for renewables), (b) the social skill and changing interplay of local actors engaged in the transition, and (c) the emergence of power-constellations and rules.

The remainder of this article is structured as follows: starting with the particularities of urban low carbon transitions, it proceeds by introducing FP as a framework to address these particularities in Section 3. Before coming to the case study, a description of the methodology and an introduction to the context of the case will be presented in Section 4. Section 5 illustrates how FP can be employed to study urban energy transitions by applying it to the case of Emden. Section 6 discusses the particularities of the case study in juxtaposition to research on other urban transitions and compares FP with the prevalent Multi-Level Perspective (MLP). The article ends with a conclusion (Section 7) highlighting policy implications and indicating further potentials for transition research.

\section{Urban Low Carbon Transitions: Agency, Networks, and Institutional Contexts}

Research on sustainability transitions has flourished in recent times (cf. Markard et al., 2012). As much of the research-implicitly or explicitly-focuses on the national level, the spatial dimension and particularly the local level have received less attention (Coenen et al., 2012; Truffer and Coenen, 2012). Nevertheless, growing scholarship on urban low carbon transitions highlights the importance and everrising engagement of cities in tackling climate change (cf. Bulkeley et al., 2013a; Bulkeley et al., 2013b; Bulkeley et al., 2014; Hodson and Marvin, 2010; Lehmann, 2014; Rutherford and Jaglin, 2015). This scholarship indicates that the dynamics of urban low carbon transitions strongly depend on (a) local agency/actors, (b) the often close social relationships in the dense urban space, (c) the institutional configuration of the local space, and (d) embeddedness in a wider socio-spatial context.

Firstly, studies outline the importance of agency in urban transitions. Powerful alliances of actors can significantly influence the shape and pace of local transitions (Hoppe et al., 2015). Different types of actors such as mayors, citizen initiatives, municipal administrations, businesses, and intermediaries may assume crucial roles, acting as initiators, facilitators or networkers of local transitions (cf. Busch and McCormick, 2014; Blanchet, 2015; Gabillet, 2015; Hargreaves et al., 2013; Mattes et al., 2015; Späth and Rohracher, 2013).

Moreover, existing insights indicate the importance of social networks, proximity, and shared visions (Darby, 2006; Hodson et al., 2013; Hoppe et al., 2015). Urban transitions are negotiated and enacted in dense social networks of key actors who often form strategic alliances. The evolution of shared guiding visions, stressing the local opportunities of the transition, further helps to align heterogeneous local actors and orientate their activities along shared goals (Späth and Rohracher, 2013, Hodson and 
Marvin, 2010; Hoppe et al., 2015). Aside from collaboration and shared visions, urban transitions are also marked by disagreement and power struggles: these are not limited to conflicts between sponsors and detractors of low carbon transitions, but also take place among its very supporters, as these follow divergent interests and promote competing visions of the local "low carbon future" (Gabillet, 2015; Rutherford and Jaglin, 2015; Späth and Rohracher, 2015). Urban low carbon transitions constitute heavily embattled matters that are negotiated in the often closely interconnected social networks of local actors.

The institutional configuration of the locality also shapes its transition dynamics: the physical space (e.g. mountain region, rural space), infrastructure (e.g. municipal utility), climate conditions (e.g. solar or wind-intense region), formal and informal norms and rules (e.g. norms of exchange), and the industrial structure of a locality set preconditions that predefine resources and barriers of local transition processes (cf. Blanchet, 2015; Broto, 2017; Mattes et al., 2015; Monstadt, 2007).

Furthermore, transition dynamics are embedded in specific regional, national and international contexts. This contextual "landscape" predefines the leeway for the given transition processes (cf. Coenen et al., 2012): for instance, absence of national political support (Rohracher and Spath, 2014; Späth and Rohracher, 2013) and the dominance of neoliberal market rationales conflicting with local ambitions (Webb, 2015) can have drastic implications for the local transition pathway.

In general terms, a theoretical approach to urban transitions has to make allowances for the specific characteristics of these transitions: local actors with heterogeneous interests, their dynamic interplay in close social relationships, and the institutional context. Taking this into account, the following section presents the Field Perspective (FP).

\section{The Field Perspective}

There are several field approaches that, despite differences in conceptualization, share a focus on the genesis, maintenance, and change of social order, for instance, Pierre Bourdieu's field theory (Bourdieu, 2006), the institutionalist field approach (DiMaggio and Powell, 1983), and Fligstein and McAdam's theory of Strategic Action Fields (SAFs) (Fligstein, 2001; Fligstein and McAdam, 2011; Fligstein and McAdam, 2012). The Field Perspective (FP) presented in this article draws mainly from Fligstein and McAdam's elaborations and partly recombines it with elements from Bourdieuian and institutionalist approaches as well as transition theory.

Fligstein and McAdam define fields as a "meso-level social order where actors (who can be individual or collective) interact with knowledge of one another under a set of common understandings about the purposes of the field, the relationships in the field (including who has power and why), and the 
field's rules" (Fligstein and McAdam, 2011: 3). Accordingly, the following elements are essential: (1) a minimum of two actors that are aware of each other, (2) (inter)action, (3) shared structures/rules, and (4) relationships including hierarchies.

Motivated by the advantages that they can generate from a privileged position and equipped with resources (e.g. money, social competences, knowledge etc.), actors within a field compete with each other over the dominant positions and advantages that are in play. The array of strategies that they employ in these struggles is limited, as the action in the field is framed by institutions: collective views, rules, and norms. The "rules of the game" (Bourdieu, 2006: 226) determine what types of action are regarded as legitimate and illegitimate. In this way, shared views, rules, norms, and models of action structure the activity in the field, often leading to resembling behavioral patterns among actors (see also DiMaggio and Powell, 1983). Moreover, hierarchies evolve out of competition, for which SAFtheory suggests distinguishing between incumbents and challengers (Fligstein and McAdam, 2011; Fligstein and McAdam, 2012). Incumbents are actors that have reached a dominant position and therefore have the highest potential of shaping the field. By contrast, challengers strive for a dominant position, competing with the incumbents. While incumbents have an interest in maintaining the status quo within the field, since their power rests on the given structure, challengers are likely to campaign for structural changes that will favor their positioning in the field.

Employing the terms "incumbents" and "challengers", SAF-theory emphasizes competition. However, fields can also be marked by high levels of collaboration, as Fligstein and McAdam (2012: 90) acknowledge. An important resource for the collaboration of actors is "social skill" (Fligstein, 2001). It refers to "the idea that people want to produce collective action by engaging others" (Fligstein and McAdam, 2011: 7). Since social skill allows actors to transcend their own interests and take other actors' interests into account, Fligstein and McAdam regard it as paramount for collaboration: it enables actors to mobilize others and create alliances. Thus, socially skilled actors are essential for field formation processes (Fligstein and McAdam, 2012: 46, 92).

A puzzling question concerns the boundaries of fields. Often membership to a field is not determined by strict rules and/or a governing body. Moreover, in many cases, field boundaries are diffuse and are themselves subject to power struggles. Bourdieu's (2006) work on the French field of art, for instance, suggests two opposing poles within the same field: The "art for art's sake" pole rejects the idea that art should be driven by any other motive than the dedication to art itself. The opposite pole is dominated by artists seeking mass appeal and economic benefits. While the "art for art's sake" pole promotes exclusive membership and closure against economic and other "profane" influences, the opposing pole of "mass-culture" endorses a more inclusive approach and stands for openness towards other fields and their logics. Accordingly, the struggle around the boundaries and membership of the 
field may become itself subject to the power struggles in the field. Moreover, the aforementioned example illustrates another feature of fields: conflicting poles hold dissimilar views regarding the legitimate purposes and rules of the field. Actors will strive to establish their view as the dominant vision of the field. In this undertaking, actors with similar views are more likely to form coalitions than actors with opposing views.

Field states and structures may change over time. Fligstein and McAdam distinguish between three field states: emergent, stable, and crisis (Fligstein and McAdam, 2011: 11-19; Fligstein and McAdam, 2012: 86, 170). While emergent fields lack encompassing rules and structures, stable fields have developed a settled structure, in the form of routines, norms, rules, and relatively established relationships between actors. A field crisis occurs when the field structures are threatened by external or internal events and potentially become subject to extensive transformations. As none of the three aforementioned states are limited to a particular time span, fields can remain for long periods of time in the state of an emergent field or even in the state of crisis. The emergence of fields can be related to state intervention or grass-roots experimentation. Transition theory highlights the importance of protective niches: these allow for the experimentation with alternatives to dominant sociotechnological configurations (Geels, 2002; Markard et al., 2012). As such, fields related to urban transition processes may emerge out of local niche experimentation.

In sum, FP conveys a social theory for the meso-level that enables the analysis of the evolution of social order and action along a limited array of elements, taking into account action, actors' interests, and the institutions (structures) framing the actions. By providing a relatively simple heuristic framework, it enables the analysis of the complex interplay of actors dedicated to a similar purpose and/or subject and the tracking of how this interplay changes over time. Given its focus on the interplay of actors within a limited "space", the field approach bears analytical potentials for unfolding urban energy transitions.

So far, there are only a few applications of FP to local energy transition processes. Fuchs et al. (Fuchs et al., 2012; Fuchs and Hinderer, 2014) provide an application to energy transition processes in Germany. They conceptualize the four main German energy providers (ENBW, E.ON, Vattenfall, and RWE) as national-level incumbents, seeking to maintain the status quo of a centralized carbon-based energy system. From this perspective, local initiatives are challengers who threaten the status quo by promoting a decentralization of electricity supply. Blanchet (2015) places a stronger emphasis on the political dimension of urban transitions, as he employs the SAF approach to describe the activities of two citizen initiatives that challenge Berlin's energy policy and struggle for a municipalization of the electricity grid in Berlin. Taking the example of solar energy in the US, Hess (2013) studies grassroots innovations with a field approach, showing processes of marginalization-blockage, countervailing 
power, and incorporation that involves an upscaling transformation of the original local grassroots solar energy models towards a national "corporate-oriented financial services regime" (Hess, 2013: 854).

The aforementioned applications of FP to local transitions limit FP to a specific range of actors (e.g. political actors, energy suppliers) and/or technologies (e.g. solar energy, grid system). Thus, they abstain from drawing a more encompassing picture of the local transformation processes. Given that urban energy transitions usually involve the interplay of a wide array of actors, this contribution proposes conceiving these transitions as social fields in which heterogeneous actors interact. These actors are simultaneously related to other social fields (local economy, politics, science etc.). The author argues that the particular value of the field perspective lies in its ability to analyze this interplay of different types of actors, interacting in the close social relationships of dense urban spaces. The following section illustrates the approach by applying it to the energy transition process in the German city Emden.

\section{Methodology and Context}

Emden is a harbor and industrial city, located in the windy coast-region of north-western Germany, with around 50,000 inhabitants. In the last few decades, Emden's economy has experienced an industrial transformation from a strong shipbuilding sector towards the wind energy sector. Politically, the city is shaped by the powerful social democratic party (Sozialdemokratische Partei Deutschlands, SPD), which has governed Emden since 1945, mostly with an absolute majority, and appoints the mayor.

Given its reputation as a pioneering city in Northern Germany's energy transition (Klagge and Brocke, 2012), Emden was chosen as a case study. The objective of the case study was to draw a relatively encompassing picture of the leading actors and their relationships. Therefore, I interviewed representatives of organizations from different backgrounds (e.g. politics, industry, civil society, science) that are involved in the local transition processes. The study also considered religious actors. Although research has, so far, barely made allowance for religious actors, these may assume important roles in sustainability transitions: they can spread worldviews and values among their followers and use their public influence and resources (e.g. media statements, influence on governments) in ways that facilitate (or block) these transitions (Koehrsen, 2017b; Koehrsen, 2018; Mohamad et al., 2012).

In total, 37 semi-structured interviews were conducted with actors from different backgrounds (see table 1). Most interviews were conducted in the office space and homes of the interviewees and, in some occasions, in cafes or via telephone. The semi-structured interview-guide consisted of open 
Urban Energy Transitions as Social Fields

questions concerning the role of the interviewee in their organization, the activities of the organization, and its relationships with other local organizations in the local energy transition, probing the interviewees for concrete examples of activities and collaboration projects. The interviews were audio recorded and transcribed. A content-analysis of the transcripts was undertaken with the support of data analysis software MaxQDa. During this process, codes for different contents (e.g. transition activities, collaborations, different views of the transitions process, power struggles) were attributed to the given sections of the transcripts. This allowed for the direct comparison of the activities and positions of the leading actors in the local transition process.

Aside from interviews, the study also included a content analysis of documents related to Emden's energy transition. The document comprises reports (e.g. European Energy Award report), press releases (e.g. press reports about the local energy provider), internet pages, flyers and information material (e.g. information about local ecology center) as well as pictures of facilities and advertisements in Emden (e.g. publicity for energy efficiency). I collected the documents via internet research and during my field trips to Emden. The documents provided additional information on the evolution of the energy transition as well as the organizations' activities and their relationships. The main results from the content analyses of the interviews and documents were compiled into a 100 page case-study report which summarizes the insights about Emden's energy transition.

\begin{tabular}{|ll|}
\hline Background & Nr. Interviews \\
\hline Politics and Administration & 6 \\
\hline Research and Science & 3 \\
\hline Business and Finance & 10 \\
\hline Civil Society & 5 \\
\hline Religion & 5 \\
\hline Intermediaries & 8 \\
\hline
\end{tabular}

Table 1: Interviewees according to background

Emden's energy transition is embedded in the context of Germany's "Energiewende" (energy transition): its objectives include a nuclear phase-out by $2022,55-60 \%$ of renewables in electricity production until 2035, and until 2050, a 50\% reduction of energy consumption, as compared to 2008 (Beveridge and Kern, 2013; The Federal Government, 2015). The implementation of national funding schemes subsidizing renewable energy production has been a popular measure to boost investments in renewables, representing more than $25 \%$ of Germany's gross electricity production today (The Federal Government, 2014). The investments in renewables are paired with a decentralization and localization of energy production and supply: while in the 1990s, Germany's government promoted the liberalization and centralization of energy provision, leading to the dominance of four big players (ENBW, E.ON, Vattenfall, and RWE) in the national energy market, the recent developments have 
prompted a decentralization of energy production and the re-emergence of local energy providers based on renewable energy production (Becker et al., 2015).

Resisting the Government's centralization strategy, Emden kept and reoriented its local energy provider, Stadtwerke Emden (SWE). Alongside SWE, numerous local actors are involved in Emden's energy transition today, such as banks, politicians, windmill manufacturers and their suppliers, renewable energy planning offices, citizen initiatives, various departments from the local university, and the municipal administration. Seeking to cultivate its image of a pioneering city, the municipality has set the ambitious climate goal to reduce $50 \%$ of its $\mathrm{CO}_{2}$ emissions by 2020, as compared to 1990 levels (Stadt Emden, 2010).

\section{Unfolding Emden's Energy Transition Field}

The following analysis outlines the evolution of the urban energy transition field, placing an emphasis on the field formation processes. Although it is split into different "evolutionary" stages, they are not clearly distinguishable and may overlap.

\section{Emergence: Niche Experimentation, Interests, and Social Skill}

The emergence of the local field is related to the first transition experiments of local actors and their increasing interaction. Of particular importance is the aforementioned reorientation of the SWE, leading to the construction of its first wind farm and energy saving campaigns among Emden's citizens in the early 1990s. As the windmills bear little chance of becoming profitable in the short run, and the energy saving campaigns risk reducing the economic turnover of the SWE, they constitute uncertain ventures in the context of a fossil-based energy regime. Nevertheless, the SWE and the city's mayor, who pushed for the re-orientation of the SWE, act along specific interests: the SWE envisages that, in the long run, its strategy of serving customers' interests in reducing their electricity bills will strengthen their loyalty to the provider. Moreover, as in other local energy transitions in Germany (Busch and McCormick, 2014; Späth and Rohracher, 2013), economic prospects are crucial: against the background of a struggling ship building industry, the mayor hopes to attract windmill manufacturers, that will create economic revenue and employment for the city, by signaling the city's interest in renewables.

The experimentation with renewables is facilitated by a local protective niche (cf. Kemp et al., 1998; Geels, 2002) which is related to an absence of political and economic competition: given that the social democratic party governs Emden, generally with an absolute majority, since 1945, the party appears to be vested against serious political competition and enjoys extensive leeway. Moreover, as the SWE 
is the only energy supplier in the territory of the city, it constitutes a monopoly. Freed from competitive pressure, the SWE and the governing party can experiment with new energy configurations.

While the niche constitutes a fertile ground for experimentation, the very transformations are initiated by socially skilled actors and advanced through their close collaboration. At this stage, the key actors pushing for these changes are an executive employee of the municipal administration, the newly appointed CEO of the SWE, an entrepreneur in renewables, and the mayor. It is only through the close collaboration of these actors that the local transition takes shape and a local field emerges. As the participation in this endeavor depends on the conviction that the transition matters, the socially skillful key actors frame "stories' that help induce cooperation" (Fligstein and McAdam, 2012: 50) and resonate with other local actors by referring to the opportunities of the transition. The efforts of persuading others ("Überzeugungsarbeit"; Interviewee 2), become-among other ways-manifest in public events and statements that help to place "energy" on the local agenda and commit other actors to the transition: for instance, in 1994, the new CEO of the SWE and the entrepreneur start to organize a biennial energy exhibition for citizens ("Emder Energietage"), hosting several local businesses and institutions. The exhibition draws attention to the financial benefits of energy efficiency and offers local companies business opportunities (e.g. refurbishments, PV installations).

The initial activities lead to the basic "settlement" of the field (Fligstein and McAdam, 2012: 92). This settlement consists of the general vision of the transition as something important and desirable. Thus, one interviewee refers to the general consensus on the importance of renewables for the region:

"(...) the energy issue in the region has been developing for a long time now. Local people have been sensitized to this topic up to a high degree. This does not only apply to actors inside the business networks, it also applies to the whole population. (...) It has been recognized in the whole region that renewable energy is very, very important. And therefore the cooperation is of high quality and straightforward." (Interviewee 31)

With different actors engaging in the local transition, interacting, and agreeing that the transition matters, a field of actors interested in the energy transition emerges. As the "settlement" does not, however, include an exact definition of the transition and how it should be pursued, these questions become subject to struggles within the field.

\section{Expansion: Exogenous Shocks, Rising Activity, and Conflicting Poles}

Since the beginning of the new millennium, exogenous shocks (Fligstein and McAdam, 2012: 19) have contributed to the settlement and expansion of the emerging field: (a) increasing concern about climate change among the German public (cf. Eurobarometer, 2008); (b) the prominent placement of the topic on the political agenda, leading to the enactment of measures furthering the German 
"Energiewende" (e.g. Germany's Renewable Energy Act) (Beveridge and Kern, 2013); (c) improved earning prospects that generate flourishing investments in renewables, particularly supporting the wind energy sector (cf. Jacobsson and Lauber, 2006; Nordensvärd and Urban, 2015).

The three exogenous developments create a fruitful context for the formation and expansion of Emden's energy transition field, rendering the engagement in the field more profitable: actors can generate different types of benefits from transition-related activities, such as political votes, power, economic profits, innovations, research funds, publications, credibility, and moral legitimacy. New actors start to participate in transition-related activities and previously involved actors expand their activities. For instance, local banks develop specific loan schemes for private home owners to finance PV-installations and energy efficient retrofitting. A massive, privately financed wind farm is constructed on the outskirts of Emden. Two, large windmill manufacturers settle in Emden, while a ship manufacturer restructures its business model and becomes a supplier for off-shore windmill manufacturers. The local university expands its research activities in sustainability and offers an undergraduate engineering degree in energy efficiency. Even some local churches undertake smaller congregation-focused projects such as the installation of solar panels, the formation of a church group to plan energy efficiency measures, and the preaching of environmental values (e.g. "integrity of creation") in sermons. However, churches do not figure among leading transition actors and describe themselves as followers rather than pioneers (Koehrsen, 2015). Asked about the role that religion assumes in the energy transitions one pastor states:

"It is secondary. Surely, there is positive support (...), but it is seldom our priority. (...) It is like jumping on a running train rather than driving the locomotive." (Interviewee 34)

In emerging fields, actors are forced to take one another into account since the structure of the field is still underdeveloped and action is taking place under high uncertainty (Fligstein and McAdam, 2012: 86-96). Collaboration reduces uncertainty and stimulates the formation of structures that can orientate further action. The rising number of collaborations and network-building efforts in Emden point to the increasing mutual awareness of local actors involved in the "Energiewende.": for instance, the local ecology center, the SWE, and the municipal administration co-organize an energy education program in all of Emden's grammar schools that sensitizes pupils in energy efficiency; and the local university and the chamber of commerce host a series of offshore wind energy conferences. The rise of collaborations results in close-knit networks that span through the local field, encouraging one observer to state:

"those persons who are engaged and involved in the projects and who are interested in regional development are networked to a high degree" (Interviewee 5). 
Despite the growing mutual awareness of local actors and the aforementioned settlement of the field-manifesting in a shared general sense that the transition matters-visions of the transition differ. As in other cities (cf. Gabillet, 2015; Rutherford and Jaglin, 2015; Späth and Rohracher, 2015; Webb, 2015), individual actors advance specific rationales of sustainability and accordingly propagate competing visions of "energy transition," representing conflicting poles of the local transition field (Fligstein and McAdam, 2012: 88-89). On the one extreme of the field, there is an opportunistic approach which regards the transition mainly as a vehicle for generating profits. Here, the particular way in which actors perceive the transition is related to the specific types of profit in their primary fields (e.g. political field = political votes), prioritizing the particular profits from their primary fields over ecological sustainability. Many businesses and some political actors tend towards this pole. For instance, a representative of a business involved in windmill construction states that the business does not pursue any climate and/or energy goals: they regard themselves "only as beneficiaries of the development towards renewables" (Interviewee 14), who would dedicate themselves to other business models if they were equally profitable. Particularly dominant at this pole is a narrative of economic gain, as actors often justify the transition solely by referring to economic profits:

"The energy transition process is of high significance now because companies in the region create a lot of value in this economic sector" (Interviewee 5).

Opposing the profit-oriented, opportunistic spectrum is the environmentalist view. These actors, represented by environmentalist groups, the green party, a protestant church, and (partly) the city's ecological center strive for a "sustainable lifestyle" (Interviewee 17) and seek to "prevent environmental degradation" (Interviewee 9). Perceiving environmental protection as an aim in itself, this pole resembles Bourdieu's exclusivist "art for art's sake" pole (Bourdieu, 2006). Between the opposed poles, stands a view which balances the two visions and to which, among others, the SWE, parts of the municipal administration, and the entrepreneur are committed.

Actors seek to promote their specific visions of the local energy transition. In particular, those actors that share compatible visions collaborate (e.g. SWE, entrepreneur and municipal administration), while actors from opposing poles (e.g. mayor and environmental groups) are likely to clash, as will be shown below. With the evolution of poles, networks, and alliances, field structures emerge which further evolve during the stabilization of the field.

\section{Stabilization: Power, Structures, and Alignment}

Actors seek to promote their own vision of the energy transition. Struggling for public visibility and impact, they vie for power in the field. Having the strongest visibility and impact, the incumbent has the highest potential to shape the field, a position that is held by the SWE: it enjoys a strong reputation 
and is seen by the vast majority of interviewees as the central player in Emden's energy transition. Most interviewees speak with admiration about the SWE, as illustrated in the following quote:

"Twenty years ago, the Emder Stadtwerke [SWE] started with their Emder Energietage here. They were the first public utility in Germany that said, "we undertake such an exhibition for consumers and push renewable energy, station a small wind turbine and speak about energy efficiency, though we normally sell electricity."'" (Interviewee 5; squared brackets by author)

The SWE maintains its incumbent position through the support of powerful allies (e.g. the entrepreneur, mayor), strong marketing efforts (e.g. poster advertisements), media coverage in the local press, a wide array of public events (e.g. evening seminars on energy efficiency), its service office in the very center of the city, its energy training program at public schools, the construction of lasting physical artefacts (e.g. wind farms) and a steady flow of new projects related to the transition (e.g. Power-To-Gas installation). The incumbent leaves little chances for challengers who have to content themselves with closely collaborating with the SWE: it secures its position by using its social skill and spanning its networks throughout the field. Thus, one interviewee was surprised when the SWE contacted and persuaded him to collaborate on a transition project that he was planning and had only mentioned to very few other actors in the field (Interviewee 29).

Given its position and activities, the SWE influences the predominant reading of the transition, which is shared by many but not all actors. This reading propagates a "green" and growth-friendly energy transition. Thus, the SWE describes itself as a sustainable energy supplier, firmly committed to $\mathrm{CO} 2$ reduction, and promises a "green future" to Emden (Stadtwerke Emden, 2016). Seeking to resonate with the economic interests of local consumers, the SWE highlights, at the same time, the (economic) benefits of renewable energy in local press statements, stating, for instance, that wind energy will become the cheapest energy source in the coming ten years (Schaller, 2010). Paralleling cases studied by Fuchs and Hinderer (2014), the predominant narrative refers to a dual motivation of strengthening the local community ("opportunities"), while acting against climate change by reducing carbon emissions ("environmental conservation").

The incumbent and its allies, seeking to impose their vision, contribute to the creation of shared structures and the alignment of field actors to these. For instance, using state-sponsored programs such as the European Energy Award and the Climate Alliance ("Klimabündnis") to fix long-term CO2 reduction objectives for the municipality, they create precedents that consolidate the predominant carbon-reduction pathway. Furthermore, the construction of massive artefacts acts as testament to the city's commitment to the low carbon transition by writing it into the physical space of Emden: vast wind farms in the outskirts of the city, solar panels at the highway leading to the city, and an immense 
solar-bunker in the very center of the city, render it visible for everyone driving into Emden that this city is strongly committed to an energy transition based on renewables. Associating the energy transition with the goal of reducing carbon emissions hints at an implicit non-carbon-extension-rule to which actors engaged in the transition field are expected to commit: their activities should not substantially contradict the $\mathrm{CO} 2$ reduction pathway (e.g. by propagating high energy consumption and/or $\mathrm{CO} 2$ intense energy production). Mutual awareness serves as a control-mechanism enforcing the non-carbon-extension-rule. Given the size of the city, the actors in the field know each other and are relatively well aware of the activities that they undertake. A violation of the rule may lead to sanctions and loss in status. An employee of a business in renewables, for instance, explains that the business' CEO hides away his brand-new SUV from another business in the local field, since such a car could speak against the environmentalist vision of its employees and impoverish their business relationship (Interviewee 13).

In total, as in other urban transitions (cf. Späth and Rohracher, 2013, Hodson and Marvin, 2010; Hoppe et al., 2015), a somehow "shared" and ill-defined vision emerges. However, as it emerges out of competition, it constitutes a dominant and contested-rather than a fully shared-vision: one that is subject to struggle and open to the possibility of change. Moreover, the field remains an emergent field: it lacks an encompassing and sophisticated system of rules and norms and a governing unit steering and controlling the activities in the field. The field may persist for long periods in this state. Before ever becoming a stable field, it can be subject to a crisis which may lead to a transformation of its current structures or even to its dissolution.

\section{Crisis: Exogenous Shocks, Conflict, and Re-Stabilization}

Just as external forces can encourage field formation processes, they can also destabilize and threaten the emerging field (Fligstein and McAdam, 2011: 15-16; Fligstein and McAdam, 2012: 19-22; 99-104). In 2008, Emden's energy transition field is hit by an external shock and drifts into an "episode of contention" (Fligstein and McAdam, 2012: 21): a Danish investor expresses interest in constructing a coal power plant in Emden's outskirts (Rysumer Nacken). Reactions differ according to the field positions of actors (Fligstein and McAdam, 2011: 9): while actors in the opportunistic pole of the field interpret the investor's plan as an opportunity to generate employment and economic revenue, actors in the environmentally concerned pole of the field regard it as a threat for the environment and the predominant transition pathway. A "window of opportunity" (Geels, 2002) opens, generating a "field crisis" (Fligstein and McAdam, 2011: 15): it offers those actors, who feel that an alternative transition pathway would be more suitable, the opportunity of enforcing their vision through the potential entrance of a new and powerful actor into the field. One interviewee from the environmental pole 
refers to what he calls the "harbor mafia" as a group of actors with strong interests in the construction of a coal power plant:

"The harbor mafia, I would call them this, is very powerful. From this milieu still comes "fuck wind energy, what we really need is a coal power plant". Or, according to them, even a nuclear power plant. (...) There is band of people with tough interests to promote their businesses in the harbor. Why do they favor coal? This is relatively simple. A coal power plant at the Rysumer Nacken would mean 1.3 million tons more turnover (...) That does not fit with our thinking. To them, we are still environmental weirdos." (Interviewee 26)

Situations of field crisis, destabilizing the structures upon which the incumbent's power rests, pose a threat to incumbents, who consequently seek to the restore the status quo (Fligstein and McAdam, 2011: 14-16). However, being bound to the support of actors from the opportunistic pole of the field (e.g. the mayor and the governing party), the SWE cannot form an open opposition to the investor's plan. Nevertheless, counterbalancing the arising power of the opportunistic pole, a powerful player emerges on the environmentally concerned pole of the field: encouraged by actors that have an interest in maintaining the transition pathway (e.g. environmental groups, the "green party," business actors related to renewables), a group of environmentally engaged citizens co-found "the citizen initiative for clean air" (Bürgerinitiative Saubere Luft e. V.) with the aim of stopping the construction of the power plant. One actor from the aforementioned group of external supporters speaks about the formation of the initiative:

"[There was] the idea to construct a coal power plant at the Rysumer Nacken by the Danish enterprise DONG (...). And then our alarm bells started ringing and we (...) thought: "What can we do?" And then it was clear, that it is the best if the citizens themselves mobilize (...) it must be the goal to bring the citizens together to bundle their energy. (....) there was a founding meeting and the citizen initiative was founded (....) the impulse came from us, and then others directly participated. Since then it has worked." (Interrviewee 17; squared brackets by author)

Powerful actors in the field mobilize a strategically important stakeholder group-Emden's citizensto act against the threat to the existing field order. Collaborating with other ecological associations such as Greenpeace and by organizing a public protest gathering up to 5000 citizens, the initiative becomes highly visible.

Theoretically, a field-crisis can produce various outcomes: (a) a change of the field structure, (b) a dissolution of the field, or (c) the survival and consolidation of the established order (Fligstein and McAdam, 2011: 18). In Emden, the "established" order prevails over those striving for an alteration of the transition pathway: the Danish investor withdraws its plans to construct a coal power plant, 
justifying its decision with a reorientation towards a more climate-friendly business strategy. Even though it cannot be established to what extent the protests ultimately contributed to the retreat of the investor, the crisis illustrates how the field forces -in the form of incumbents, allies, rules-strive to stabilize the predominant transition pathway, which relies on $\mathrm{CO}_{2}$ reduction through heavy investments in wind energy and energy efficiency.

\section{Discussion}

In the course of the interplay of local actors, Emden's energy transition field emerges. The field is marked by high levels of collaboration, socially skilled leading actors, a shared understanding regarding its importance, and differing visions/interests. The local protective niche, exogenous shocks, the engagement of key actors, and their social skill are particularly important for the formation of the local transition field: while the local protective niche allows for early experimentation with renewables and the social skill of pioneering actors persuades other powerful actors that the transition matters, exogenous shocks in the form of state sponsorship accelerate the settlement and expansion of the emerging field. The case study shows that the evolution of a field can create resilience in ongoing transition processes. Against the backdrop of a threating external intervention, Emden's field forces mobilize against an alteration of the prevalent pathway.

As the incumbent and its allies promote the low carbon transformation of the city's energy system, the case of Emden contrasts other FP studies in which carbon-based energy incumbents shape the predominant visions of energy and field rules (cf. Fuchs et al., 2012; Fuchs and Hinderer, 2014) and thereby secure a "carbon-lock-in" (Unruh, 2000). Depending on the local constellations of actors and institutions, urban energy transition fields develop different dynamics. They are marked by higher levels of conflict than in Emden, when longstanding incumbents seek to secure a carbon-based energy system and are contested by environmentally engaged challengers: in contrast to the case of Emden, Berlin's energy transition is shaped by heavy struggles about the municipalization of the electricity grid (Blanchet, 2015). Similarly, strong conflicts about the construction of a nuclear power plant in the outskirts of Freiburg in 1975 marked the beginning of the city's energy transition (Späth and Rohracher, 2013). Aside from varying in the degree of conflict, local transition fields differ in the centralization of power. Intermediary organizations frequently shape urban energy transitions, thereby potentially centralizing the power within these fields (Hargreaves et al., 2013). In the case of the German city Bottrop, the intermediary organization Innovation City $\mathrm{GmbH}$ governs the local energy transition processes, coordinating most activities within the field, thereby accumulating high levels of power (Koehrsen, 2017a; Mattes et al., 2015). In the case of Greater Manchester, several intermediaries have even been set up to support and coordinate transition projects in the city region (Hodson and Marvin, 
2012). By coordinating local activities and setting long-term goals, these organizations may further stabilize the transition pathways of fields. By contrast, in Emden a powerful intermediary organization coordinating the local transition processes has not evolved. Moreover, local energy fields vary on additional dimensions, such as their interference with other fields (e.g. local industry), the level of stabilization (e.g. stability of field rules), the number and plurality of actors, and density of social networks. Depending on these factors, local energy transition fields develop unique transition dynamics (cf. Hodson and Marvin, 2010) that can be analyzed and compared based on FP.

Beside the particularities of the case analyzed here, FP conveys a specific perspective on transitions. Comparing FP with the prominent Multi-Level Perspective (MLP) (cf. Geels, 2002) helps to illustrate the particularities of the approach. MLP distinguishes between three levels: landscape, regime, and niche (cf. Geels, 2002). Regimes constitute stable socio-technological configurations that allow only for incremental change. In contrast, experimentation with more radical innovation takes places in niches, often in the form of protective spaces. Changes on the landscape level-the more general context of the society-may create "windows of opportunity" for niche innovation and allow for change to the existing socio-technological configuration.

While paralleling MLP in many features-both frameworks study rivalry about the dominant social order and agree on the importance of exogenous factors for changing this order-FP contrasts MLP when it comes to the concept of niches. Instead of assuming that innovation evolves in protected spaces, FP suggests that incumbents and challengers compete in the very same social space over shaping the social order. Thereby, FP better fits the dynamics of urban energy transitions: in smallscale spaces with dense social networks (e.g. medium size cities), strong boundaries between "niches" and "regimes" will usually not evolve. Though the niche-character of Emden's energy system may explain the early experimentation with renewables, the later dynamics of the field depend on the direct competition and collaboration of actors with heterogeneous interests. The proximity of actors and close-knit networks in the local space render it impossible to classify actors, processes, and structures along the dichotomy of "regimes" and "niches" (Bulkeley et al., 2013a; Hoppe and van Bueren, 2015; Späth and Rohracher, 2013). The case also challenges the general distinction between supporters (regime-actors) and inhibitors (niche-actors) of low carbon transitions. The case of Emden illustrates that rivalry takes place between the very actors that seek to render societies more sustainable. Since notions of "sustainability" and "energy transition" are ambivalent and the engagement in transitions is often related to dissimilar types of benefits, actors are likely to promote competing visions of what the "low carbon future" should be (cf. Hess, 2013: 853; Späth and Rohracher, 2015; Walker and Shove, 2007; Woolthuis et al., 2013). Applying FP suggests that, instead of drawing upon prefixed classifications, we need to more closely study actors' motivations for 
engaging in energy transitions and how their visions and activities interact with those of other actors to evolve into transition pathways.

\section{Conclusion}

Although cities and towns are conceived of as hotbeds of low carbon transitions (Bulkeley et al., 2013a; Bulkeley et al., 2013b; Hodson and Marvin, 2010; Lehmann, 2014; Rutherford and Jaglin, 2015), there is a shortage of theoretical approaches that untangle the complex interplay of different types of actors in the course of these local transformations (Truffer and Coenen, 2012). Against this background, FP offers a comprehensive framework to study this interplay, highlighting the collaboration and competition between different types of actors, the evolution of power-constellations and rules, and the influence of the field-environment on local transition dynamics (Fuchs et al., 2012; Fuchs and Hinderer, 2014).

Given that FP conveys an approach for describing social action at the meso-level (Fligstein and McAdam, 2011; Fligstein and McAdam, 2012), it provides a heuristic tool to craft a comprehensive overview of the actors, their positions, and their relationships in urban energy transitions: it allows for the ordering of the vast amount of actors involved in these processes, identifying which actors hold which positions, which views and actors are dominant, and how actors relate to each other in terms of competition and collaboration.

Aside from offering a heuristic tool, FP shows that social interaction and the evolution of social order are crucial for energy transitions. In the course of the interplay between local actors, social rules, visions, networks, and hierarchies evolve. The evolving social order structures the energy transition process: shared rules, predominant views, and the leadership of incumbent actors create dominant pathways, pushing actors' activities into a particular direction and impeding major deviations. However, actors holding alternative visions may survive in the margins of the field and overturn its structures, when forming powerful alliances or exogenous shocks open up a "window of opportunity" (Geels, 2002). Therefore, FP enables not only the study of constellations that stabilize specific pathways or "lock-ins," but also the analysis of constellations that lead to extensive transformations: it suggests that there are particular phases of contestation in which competition rises above normal levels and pathways may change (see also Späth and Rohracher, 2015). In these phases, it depends on the stability of field structures as to whether established transition pathways prevail. As the case of Emden shows, transition fields can create resilience against change, responding to external threats by mobilizing field forces. 
Transition fields react to exogenous interventions according to their social order, potentially resisting external efforts to change their pathway. Given this self-organizing nature of fields, ongoing urban energy transitions cannot be easily managed by external policy actors. As such, the outcomes of the FP analysis point towards caution when it comes to the management of urban energy transitions (see also Broto, 2017; Shove and Walker, 2007): there is no viable way of directly steering the complex social processes that occur during these transformations processes. Nevertheless, FP proposes two mechanisms through which the social order of a field can be alternated: (a) exogenous shocks (external policy intervention) and (b) internal power struggles (internal policy intervention). For both mechanisms, there is a need to develop policies aware of field dynamics and take into account the evolution of social order and the vested interests of individual actors.

External policy makers (e.g. national and regional administrators) might consider creating contexts that facilitate the formation of urban energy transition fields. Field formation is based on the actors' interest in the purpose of the field and the mutual awareness of these actors. Therefore, policy measures aiming towards field formation should promote the exchange of local actors (e.g. statesponsored municipal networking programs involving local stakeholders) and raise their specific interests in transition processes (e.g. feed-in-tariffs for decentralized renewables for businesses and citizens, local level research funds for researchers). The case of Emden challenges policy approaches which focus on smaller sets of energy-related actors (e.g. energy suppliers and consumers): given the participation of diverse actors from different backgrounds (e.g. businesses, politicians, researchers, citizens) in urban energy transitions, there is need for schemes that consider the wide range of involved actors and mediate their dissimilar interests. To this end, external policy interventions can promote the foundation of intermediaries. These intermediaries need to take the diverse stakeholder groups into account, assess their individual interests, and build bridges between them. Furthermore, external policy makers might consider empowering those local actors that promote their proposed transition pathway (e.g. offering financial support to local energy providers focusing on renewables), allowing them to eventually become incumbents and shape the local field.

In contrast to external policy actors, local policy makers are part of the very field that they try to shape. As they are embedded in the power relations, form part of the struggles to shape the transition, and see their own interests at stake, they cannot assume an external perspective (Shove and Walker, 2007). Within the field, they will not be the only powerful players. In many cases, other actors (e.g. energy companies, citizens) will have more influence on the pathway of the transition. To influence processes, local policy actors will, therefore, have to create alliances. FP highlights the importance of "social skill": local policy actors need to recognize the particular interests of different types of actors, take them seriously, and mediate between them in a way that leads to a more or less shared interest in the 
pursued transformation process. In this view, the role of local policy makers is similar to the abovementioned intermediaries: local policy making becomes the managing of diverse interests and persuading other actors to move into a direction that matches with the visions of the local administration. For instance, Emden's ex-mayor considered the interests of different actors (e.g. economic profit, environmental protection, fair energy prices), brought them together in his strategy to create a pioneering city in Northern Germany's energy transition, but at the same time remained committed to the administration's policy goals (e.g. creating employment). Moreover, local policy makers can use their resources (e.g. social contacts, hiring of staff) to empower local actors that share their interest in the persuaded transition pathway. As such, Emden's ex-mayor used his influence to hire a CEO for the city's energy provider that showed a strong interest in renewables and energy efficiency. Finally, once the field is moving in a direction that matches their intended transition pathway, policy makers need to consider measures to stabilize the field. This is to vest it against the destabilizing influence of exogenous shocks and internal competition which may divert the field dynamics from the once-established pathway. Creating shared commitment within the field among the most powerful players by fixing long term goals, designing joint strategies, and creating social control mechanisms (e.g. meetings in which local actors regularly report their activities) facilitates creating this stability.

Despite constituting a fruitful heuristic approach, FP also faces limitations and needs to be further adapted to the specific research topic of sustainability transitions. More applications of FP could elaborate on the role of "social skill" in field formation processes and the creation of field stability. In particular, comparative research on local transition processes in different national and regional contexts will provide a more thorough understanding of field formation patterns and their dependency on local and exogenous factors. Such comparative research may potentially identify various "idealtypes" of transition fields (e.g. collaborative vs. competitive, centralized vs. decentralized transition fields) provoking different local transition dynamics. Collecting data on "ideal-types" of urban energy transition fields and studying their development patterns under varying internal and external conditions may help to create nuanced policy advice that fits specific field-constellations

\section{Acknowledgements}

The author is grateful for the helpful remarks from Philipp Späth, Sarah Darby, the members of the Energy Research Programme at Oxford's Environmental Change Institute, Helen Gilroy, Michelle Witen, the anonymous reviewers, as well as for the support of Jannika Mattes and Andreas Huber. The 
Urban Energy Transitions as Social Fields

empirical research was funded by ADEME (Agence de l'environnement et de la maîtrise de l'énergie) and undertaken as part of the project COMPOSITE.

\section{References}

Becker, S., Beveridge, R., Naumann, M., 2015. Remunicipalization in German cities: contesting neoliberalism and reimagining urban governance? Space and Polity 19 (1), 76-90. 10.1080/13562576.2014.991119.

Beveridge, R., Kern, K., 2013. Energiewende in Germany: Background, Developments and Future Challenges, The. Renewable Energy L. \& Pol'y Rev., 3.

Blanchet, T., 2015. Struggle over energy transition in Berlin: How do grassroots initiatives affect local energy policy-making? Energy Policy 78, 246-254. 10.1016/j.enpol.2014.11.001.

Bourdieu, P., 2006. The rules of art: Genesis and structure of the literary field. Stanford Univ. Press, Stanford, Calif., 408 pp.

Broto, V.C., 2017. Energy landscapes and urban trajectories towards sustainability. Energy Policy. 10.1016/j.enpol.2017.01.009.

Bulkeley, H., Broto, V.C., Hodson, M., Marvin, S., 2013a. Introduction, in: Bulkeley, H., Castán Broto, V., Hodson, M., Marvin, S. (Eds.), Cities and low carbon transitions. Routledge, London, pp. 1-10.

Bulkeley, H., Castán Broto, V., Hodson, M., Marvin, S. (Eds.), 2013b. Cities and low carbon transitions. Routledge, London, 205 pp.

Bulkeley, H., Edwards, G.A.S., Fuller, S., 2014. Contesting climate justice in the city: Examining politics and practice in urban climate change experiments. Global Environmental Change 25, 31-40. 10.1016/j.gloenvcha.2014.01.009.

Busch, H., McCormick, K., 2014. Local power: exploring the motivations of mayors and key success factors for local municipalities to go $100 \%$ renewable energy. Energ Sustain Soc 4 (1), 1-15. 10.1186/2192-0567-4-5.

Coenen, L., Benneworth, P., Truffer, B., 2012. Toward a spatial perspective on sustainability transitions: Special Section on Sustainability Transitions. Research Policy 41 (6), 968-979. 
Urban Energy Transitions as Social Fields

Darby, S., 2006. Social learning and public policy: Lessons from an energy-conscious village. Energy Policy 34 (17), 2929-2940. 10.1016/j.enpol.2005.04.013.

DiMaggio, P.J., Powell, W.W., 1983. The Iron Cage Revisited: Institutional Isomorphism and Collective Rationality in Organizational Fields. American Sociological Review 48 (2), 147-160. $10.2307 / 2095101$.

Eurobarometer, 2008. Attitudes of European citizens towards the environment: Results for Germany. http://ec.europa.eu/public_opinion/archives/ebs/ebs_295_sheet_de.pdf. Accessed 25 May 2016.

Fligstein, N., 2001. Social skill and the theory of fields. Sociological Theory 19 (2), 105-125.

Fligstein, N., McAdam, D., 2011. Toward a General Theory of Strategic Action Fields. Sociological Theory 29 (1), 1-26. 10.1111/j.1467-9558.2010.01385.x.

Fligstein, N., McAdam, D., 2012. A theory of fields. Oxford University Press, New York, xiv, 238.

Fuchs, G., Hinderer, N., 2014. Situative governance and energy transitions in a spatial context: case studies from Germany. Energ Sustain Soc 4 (1), 16. 10.1186/s13705-014-0016-6.

Fuchs, G., Hinderer, N., Kungl, G., Neukirch, M., 2012. Adaptive Capacities, Path Creation and Variants of Sectoral Change. The Case of the Transformation of the German Energy Supply System. http://www.uni-

stuttgart.de/soz/oi/publikationen/soi_2012_2_fuchs_hinderer_kungl_neukirch_adaptive_capacit ies.pdf.

Gabillet, P., 2015. Energy supply and urban planning projects: Analysing tensions around district heating provision in a French eco-district. Energy Policy 78, 189-197. 10.1016/j.enpol.2014.11.006. Geels, F.W., 2002. Technological transitions as evolutionary reconfiguration processes: a multi-level perspective and a case-study. Research Policy 31 (8-9), 1257-1274.

Hargreaves, T., Hielscher, S., Seyfang, G., Smith, A., 2013. Grassroots innovations in community energy: The role of intermediaries in niche development. Global Environmental Change 23 (5), 868-880. 10.1016/j.gloenvcha.2013.02.008. 
Urban Energy Transitions as Social Fields

Hess, D.J., 2013. Industrial fields and countervailing power: The transformation of distributed solar energy in the United States. Global Environmental Change 23 (5), 847-855. 10.1016/j.gloenvcha.2013.01.002.

Hodson, M., Marvin, S., 2010. Can cities shape socio-technical transitions and how would we know if they were? Research Policy 39 (4), 477-485. 10.1016/j.respol.2010.01.020.

Hodson, M., Marvin, S., 2012. Mediating Low-Carbon Urban Transitions? Forms of Organization, Knowledge and Action. European Planning Studies 20 (3), 421-439. 10.1080/09654313.2012.651804.

Hodson, M., Marvin, S., Bulkeley, H., Broto, V.C., 2013. Conclusion, in: Bulkeley, H., Castán Broto, V., Hodson, M., Marvin, S. (Eds.), Cities and low carbon transitions. Routledge, London, pp. 198-202. Hoppe, T., Graf, A., Warbroek, B., Lammers, I., Lepping, I., 2015. Local Governments Supporting Local Energy Initiatives: Lessons from the Best Practices of Saerbeck (Germany) and Lochem (The Netherlands). Sustainability 7 (2), 1900-1931. 10.3390/su7021900.

Hoppe, T., van Bueren, E., 2015. Guest editorial: governing the challenges of climate change and energy transition in cities. Energ Sustain Soc 5 (1), 88. 10.1186/s13705-015-0047-7.

Jacobsson, S., Lauber, V., 2006. The politics and policy of energy system transformation-explaining the German diffusion of renewable energy technology. Energy Policy 34 (3), 256-276. 10.1016/j.enpol.2004.08.029.

Kemp, R., Schot, J., Hoogma, R., 1998. Regime shifts to sustainability through processes of niche formation: The approach of strategic niche management. Technology Analysis \& Strategic Management 10 (2), 175-198. 10.1080/09537329808524310.

Klagge, B., Brocke, T., 2012. Decentralized electricity generation from renewable sources as a chance for local economic development: a qualitative study of two pioneer regions in Germany. Energy, Sustainability and Society 2 (5), 2-9.

Koehrsen, J., 2015. Does religion promote environmental sustainability? - Exploring the role of religion in local energy transitions. Social Compass 62 (3), 296-310. 10.1177/0037768615587808. 
Urban Energy Transitions as Social Fields

Koehrsen, J., 2017a. Boundary Bridging Arrangements: A Boundary Work Approach to Local Energy Transitions. Sustainability 9 (424). 10.3390/su9030424.

Koehrsen, J., 2017b. Religious Agency in Sustainability Transitions: Between Experimentation, Upscaling, and Regime Support. Environmental Innovation and Societal Transitions. 10.1016/j.eist.2017.09.003.

Koehrsen, J., 2018. Eco-Spirituality in Environmental Action: Studying Dark Green Religion in the German Energy Transition: Journal for the Study of Religion, Culture and Nature 12 (1).

Lehmann, S., 2014. Low carbon cities: Transforming urban systems. Routledge.

Markard, J., Raven, R., Truffer, B., 2012. Sustainability transitions: An emerging field of research and its prospects. Research Policy 41 (6), 955-967. 10.1016/j.respol.2012.02.013.

Mattes, J., Huber, A., Koehrsen, J., 2015. Energy transitions in small-scale regions - what we can learn from a regional innovation systems perspective. Energy Policy 78, 255-264. 10.1016/j.enpol.2014.12.011.

Mohamad, Z.F., Idris, N., Mamat, Z., 2012. Role of religious communities in enhancing transition experiments: A localised strategy for sustainable solid waste management in Malaysia. Sustain Sci 7 (2), 237-251. 10.1007/s11625-012-0169-1.

Monstadt, J., 2007. Urban governance and the transition of energy systems: Institutional change and shifting energy and climate policies in Berlin. International Journal of Urban and Regional Research 31 (2), 326-343.

Nordensvärd, J., Urban, F., 2015. The stuttering energy transition in Germany: Wind energy policy and feed-in tariff lock-in. Energy Policy 82, 156-165. 10.1016/j.enpol.2015.03.009.

Rohracher, H., Spath, P., 2014. The Interplay of Urban Energy Policy and Socio-technical Transitions: The Eco-cities of Graz and Freiburg in Retrospect. Urban Studies 51 (7), 1415-1431. 10.1177/0042098013500360.

Rutherford, J., Jaglin, S., 2015. Introduction to the special issue - Urban energy governance: Local actions, capacities and politics. Energy Policy 78, 173-178. 10.1016/j.enpol.2014.11.033. 
Urban Energy Transitions as Social Fields

Schaller, J., 2010. SWE arbeiten weiter an ihrer "Mission Grün". Emder Zeitung.

Shove, E., Walker, G., 2007. CAUTION!: Transitions ahead: politics, practice, and sustainable transition management. Environ. Plann. A 39 (4), 763-770. 10.1068/a39310.

Späth, P., Rohracher, H., 2013. The 'eco-cities' Freiburg and Graz: The social dynamics of pioneering urban energy and climate governance, in: Bulkeley, H., Castán Broto, V., Hodson, M., Marvin, S. (Eds.), Cities and low carbon transitions. Routledge, London, pp. 88-106.

Späth, P., Rohracher, H., 2015. Conflicting strategies towards sustainable heating at an urban junction of heat infrastructure and building standards. Energy Policy 78, 273-280. 10.1016/j.enpol.2014.12.019.

Stadt Emden, 2010. Integriertes Kommunales Klimaschutzkonzept. https://www.emden.de/ fileadmin/media/stadtemden/PDF/FB_300/FD_362/Energie_Klima/klimaschutzkonzept_gesamt_ endversion.pdf. Accessed 20 September 2014.

Stadtwerke Emden, 2016. Verantwortung übernehmen die Zukunft gestalten. https://stadtwerkeemden.de/unternehmen/verantwortung/. Accessed 26 August 2016.

The Federal Government, 2014. Energiewende: Anteil Erneuerbarer Energien wächst weiter. http://www.bundesregierung.de/Content/DE/Artikel/2014/01/2014-01-13-bdew-energiebilanz2013.html. Accessed 27 August 2016.

The Federal Government, 2015. Energiewende: Maßnahmen im Überblick. http://www.bundesregierung.de/Content/DE/StatischeSeiten/Breg/Energiekonzept/0-

Buehne/ma\%C3\%9Fnahmen-im-

ueberblick.html;jsessionid=384458BD8066B80D628516114515E39C.s4t1. Accessed 18 September 2015.

Truffer, B., Coenen, L., 2012. Environmental innovation and sustainability transitions in Regional Studies. Regional Studies 46 (1), 1-21.

Unruh, G.C., 2000. Understanding carbon lock-in. Energy Policy 28 (12), 817-830. 10.1016/S03014215(00)00070-7. 
Urban Energy Transitions as Social Fields

Walker, G., Shove, E., 2007. Ambivalence, Sustainability and the Governance of Socio-Technical Transitions. Journal of Environmental Policy \& Planning 9 (3-4), 213-225. $10.1080 / 15239080701622840$.

Webb, J., 2015. Improvising innovation in UK urban district heating: The convergence of social and environmental agendas in Aberdeen. Energy Policy 78, 265-272. 10.1016/j.enpol.2014.12.003.

Woolthuis, R.K., Hooimeijer, F., Bossink, B., Mulder, G., Brouwer, J., 2013. Institutional entrepreneurship in sustainable urban development: Dutch successes as inspiration for transformation. Journal of Cleaner Production 50, 91-100. 